\title{
CORPORATE SOCIAL RESPONSIBILITY DAN EARNINGS MANAGEMENT: MANAGERIAL ENTRENCHMENT SEBAGAI VARIABEL MODERASI
}

\author{
Steven Khosasi ${ }^{1}$, Rizky Eriandani ${ }^{2}$ \\ 1,2 Universitas Surabaya, Surabaya, Indonesia \\ Email korespondensi: ${ }^{2}$ rizky.eriandani@staff.ubaya.ac.id
}

\begin{abstract}
ABSTRAK
Penelitian ini bertujuan menguji pengaruh managerial entrenchment terhadap hubungan tanggung jawab sosial perusahaan (CSR) dengan praktik manajemen laba. Data yang digunakan adalah semua perusahaan sektor manufaktur yang terdaftar di BEI periode 2016-2018. Proksi yang digunakan untuk mengukur managerial entrenchment adalah kepemilikan saham CEO dan masa jabatan CEO. Pengolahan data menggunakan moderated regression analysis. Hasil penelitian yang diperoleh menyatakan bahwa tanggungjawab sosial perusahaan berpengaruh negatif terhadap manajemen laba, sedangkan masa jabatan CEO dan kepemilikan saham CEO tidak memberikan pengaruh terhadap hubungan tanggung jawab sosial perusahaan dengan manajemen laba. Selain itu, pada penelitian ini juga menemukan bahwa masa jabatan CEO memiliki pengaruh yang signifikan terhadap kesenjangan tanggung jawab sosial perusahaan. Penelitian ini memberikan implikasi bahwa walaupun managerial entrenchment tidak merusak hubungan CSR dan tindakan manajemen laba, namun managerial entrenchment menentukan jenis aktifitas CSR yang dilakukan perusahaan.
\end{abstract}

Kata kunci: corporate social responsibility; kepemilikan manajerial; manajemen laba, managerial entrenchment; masa jabatan chief executive officer

\begin{abstract}
This study aims to examine the effect of managerial entrenchment on the relationship between corporate social responsibility (CSR) and earnings management practices. The data used are all manufacturing sector companies listed on the IDX for the 2016-2018 period. The proxies used to measure managerial entrenchment are CEO's share ownership and CEO's tenure. Data processing using moderated regression analysis. The results obtained indicate that corporate social responsibility harms earnings management. At the same time, the tenure of the CEO and CEO's share ownership does not affect the relationship between corporate social responsibility and earnings management. In addition, this study also found that CEO tenure has a significant influence on the corporate social responsibility gap. This study implies that although managerial entrenchment does not damage the relationship between CSR and earnings management actions, managerial entrenchment determines the company's types of CSR activities.
\end{abstract}

Keywords: chief executive officer tenure; corporate social responsibility; earnings management; managerial entrenchment; managerial ownership

\section{KETERANGAN ARTIKEL}

Riwayat Artikel: diterima: 9 Januari 2021; direvisi: 23 Maret 2021; disetujui: 15 Juni 2021

Klasifikasi JEL: M14, M41

Cara mensitasi: Eriandani, R., \& Khosasi, S. (2021). Corporate Social Responsibility dan Earnings Management: Managerial Entrenchment sebagai Variabel Moderasi. JIAFE (Jurnal Ilmiah Akuntansi Fakultas Ekonomi), 7(1), 23-34. https://doi.org/10.34204/jiafe.v7i1.2869 
Steven Khosasi: Corporate Social Responsibility ...

\section{PENDAHULUAN}

Kinerja corporate social responsibility (CSR) diyakini dapat mendorong kinerja keuangan perusahaan (Eriandani, 2020; Fatemi, Glaum, \& Kaiser, 2018; Liu \& Lu, 2019). Tanggung jawab sosial harus dilakukan oleh perusahaan yang bersentuhan dengan alam karena sebagian besar bahan baku produksi yang digunakan berasal dari sumber daya alam dan juga mempengaruhi limbah yang dihasilkan oleh perusahaan. Selain itu, sejumlah penelitian telah memberikan bukti tentang tanggung jawab sosial terkait dengan perilaku dalam membantu perusahaan mengelola legitimasi mereka, menemukan hubungan positif antara upaya CSR perusahaan dan evaluasi produk mereka, manajemen hubungan pelanggan dan perlakuan dari peraturan (Hong \& Liskovich, 2015; Perera \& Chaminda, 2013). CSR juga terbukti memberikan berbagai manfaat pada perusahaan - menurunkan risiko (Eriandani \& Wijaya, 2021; Nguyen \& Nguyen, 2015); meningkatkan reputasi, dan meningkatkan nilai pasar perusahaan (Lee, 2020).

Namun, dalam beberapa hal, CSR seringkali disalahgunakan oleh perusahaan sebagai salah satu cara untuk meningkatkan citra perusahaan kepada publik atau masyarakat misalnya menurut mengemukakan bahwa perusahaan dapat melaporkan kinerja lingkungan dengan cara terlalu optimis dan sepihak yang biasa dikenal sebagai praktik "greenwashing" (Lyon \& Montgomery, 2015). Namun sulit bagi pihak luar untuk mendapatkan informasi tentang bagaimana aktivitas CSR dikaitkan dengan nilai perusahaan, manajer perusahaan mungkin memiliki insentif oportunis dalam kondisi asimetri informasi. Di bawah asimetri informasi, manajer dihadapkan pada insentif untuk memperlihatkan praktik perusahaan yang baik melalui keterlibatan CSR yang tinggi dengan tujuan memperoleh keuntungan pribadi mereka (Suto \& Takehara, 2020). Berdasarkan fakta empiris tersebut, penting untuk melihat apakah aktivitas CSR yang dilakukan mendorong perilaku etis atau sebaliknya. Dalam penelitian ini menganalisis perilaku etis dengan menggunakan tindakan manipulasi laba.

Dalam beberapa literatur mengemukakan bahwa keterkaitan praktik CSR dengan earnings management (EM) adalah hubungan yang negatif dimana kenaikan satu variabel menyebakan penurunan nilai dari variabel lainnya. Hasil empiris mengkonfirmasi dampak negatif dari tindakan CSR pada manajemen laba dengan mengemukakan bahwa perusahaan yang memiliki komitmen terhadap CSR kurang terlibat dalam tindakan manajemen laba (Gras-Gil dkk., 2016). Kemudian manipulasi pendapatan, yang menurut banyak orang tidak pantas secara etika, terjadi lebih jarang di perusahaanperusahaan dengan komitmen kuat terhadap tanggung jawab sosial (Botero dkk., 2004). Scholtens \& Kang (2013) menganalisis hubungan timbal balik antara CSR, perlindungan investor, dan manajemen pendapatan untuk 139 perusahaan di sepuluh negara Asia, menyimpulkan bahwa bahwa perusahaan yang berkinerja lebih baik dalam CSR terlibat secara signifikan lebih sedikit dalam manajemen laba. Hasil ini juga sama dengan literatur lainnya dengan menggunakan sample di United Kingdom yang menyatakan bahwa perusahaan dengan komitmen yang lebih tinggi untuk kegiatan CSR cenderung kecil kemungkinannya dalam mengelola pendapatan melalui akrual (Almahrog dkk., 2018).

Sebaliknya, pelaksanaan CSR juga dapat mendorong tindakan memanipulasi laba jika dihubungkan dengan implementasi inisiatif entrenchment. Dari sudut pandang ini, mendapatkan pengakuan dari aktivis kelompok sosial merupakan strategi bagi CEO yang menghadapi tekanan. Mangerial entrenchment dapat dikatakan sebagai tindakan manajer yang mengutamakan dirinya sendiri. Saat dikaitkan dengan CSR, maka aktivitas tersebut dilakukan dengan motif oportunis. Hasil penelitian GarcíaSánchez dkk. (2020) mengungkapkan bahwa hubungan antara kinerja CSR dan EM menjadi positif di hadapan managerial entrenchment. Selain itu, dengan mempertimbangkan CEO tenure, CEO entrenchment meningkat dari waktu ke waktu (Shen, 2003) yang dimana masa jabatan ceo proksi untuk meningkatkan kekuasaan CEO atas pemilik (Dikolli dkk., 2014) dan CEO ownership, sebuah hubungan yang jelas antara struktur kepemilikan dan akrual diskresioner manajer yang memiliki dampak yang signifikan pada besarnya manajemen laba (Kazemian \& Sanusi, 2015). Berdasarkan uraian diatas, 
penelitian ini bertujuan menganalisis pengaruh managerial entrenchment terhadap hubungan tanggung jawab sosial dan manajemen laba di Indonesia, dengan menggunakan variabel CEO tenure dan CEO ownership sebagai ukuran dalam mengukur managerial entrenchment.

Penelitian ini akan memperkaya literatur dengan memberikan dua kontribusi. Pertama, mengevaluasi kembali hubungan CSR dan earnings management dan menambahkan variabel manajerial entrenchment sebagai variabel moderasi. Kedua, menganalisis apakah aktivitas CSR dapat digunakan sebagai alat untuk managerial entrenchment, dimana perusahaan memisahkan tindakan CSR untuk menyamarkan strategi yang bersifat oportunis.

\section{KAJIAN LITERATUR DAN PENGEMBANGAN HIPOTESIS Manajerial Entrenchment}

Teori agensi menyatakan bahwa pengawasan pada perusahaan secara efektif akan menghindari tindakan ekspropriasi asset oleh manajer. Manajerial Entrenchment adalah kondisi dimana tata kelola perusahaan dan mekanisme control yang lemah (Wang, 2011). Kemudian literatur lain menyatakan bahwa dalam menghadapi mekanisme pemantauan yang tidak efektif dan ketersediaan peluang, manajer dapat mengikuti kepentingan mereka dengan mengorbankan investor. Mereka berusaha untuk memenuhi tujuan pribadi untuk mempertahankan pekerjaan mereka dan menghindari pengawasan pemangku kepentingan daripada mencapai tujuan perusahaan (Muriithi, 2021). Tata kelola yang lemah memberi ruang kepada manajer untuk memprioritaskan tujuan pribadi mereka di atas tujuan perusahaan (Bebchuk, dkk., 2009). Di sisi lain, ini juga terkait dengan praktik pelaporan keuangan berkualitas rendah. Hal tersebut menunjukkan bahwa terdapat hubungan antara managerial entrenchment dan manipulasi laba.

\section{Corporate Social Responsibility dan Earnings Management}

Tindakan CSR memiliki peran penting yang mencerminkan aspek etika dan moral perusahaan. Secara tidak langsung, permasalahan kompleks yang ada dalam perusahaan seperti masalah manajemen sumber daya manusia, perlindungan lingkungan dan lain sebagainya dapat teratasi oleh tindakan CSR yang dilakukan perusahaan (McWilliams, 2011). Selain mengatasi permasalahan, tindakan CSR juga meningkatkan kepuasan pemangku kepentingan serta memberikan efek positif terhadap reputasi perusahaan (Liu \& Lu, 2019) dan mengurangi risiko keuangan yang ditanggung oleh perusahaan (Liu \& Lu, 2019). Oleh karena itu, dengan adanya tindakan CSR yang diambil oleh perusahaan membuat perusahaan cenderung tidak melakukan manajemen laba (Hong \& Andersen, 2011). Manajemen laba mengarah pada kualitas laba yang lebih rendah, itu mengurangi kemampuan prediksi laba masa depan dan arus kas.

Tanggung jawab sosial perusahaan difokuskan tidak hanya pada peningkatan keuntungan saat ini tetapi juga pada membina hubungan masa depan dengan pemangku kepentingan. Dari sudut pandang ini, perusahaan yang bertanggung jawab secara sosial memiliki kecenderungan untuk meminimalkan keuntungan jangka pendek dan memaksimalkan keuntungan atau berfokus pada hubungan jangka panjang dengan para pemangku kepentingan. Hal ini disebabkan karena pemangku kepentingan memiliki kontrol penuh terhadap sumber daya yang penting bagi eksistensi perusahaan, sedangkan seorang manajer yang menginginkan keberlanjutan perusahaan harus secara strategis menuangkan perhatiannya pada kebutuhan pemangku kepentingan (Choi, Lee, \& Park, 2013). Maka dari itu, CSR dapat mengurangi insentif untuk mengelola laba sebab tindakan CSR dapat memitigasi masalah keagenan, terutama konflik keagenan antar pengendalian pemegang saham dan pemegang saham minoritas (Scholtens \& Kang, 2013).

$\mathrm{H}_{1}$ : semakin baik kinerja corporate social responsibility akan semakin rendah earnings management 


\section{CEO Tenure, Corporate Social Responsibility, dan Earning Management}

Seorang eksekutif yang memanipulasi pendapatan memiliki insentif untuk menggambarkan citra ramah sosial, mengingat bahwa tindakan CSR merupakan alat yang kuat untuk mendapatkan dukungan dari para pemangku kepentingan. Hal tersebut akan mengurangi kemungkinan manajer dipecat karena tekanan dari pemegang saham yang tidak puas atau para pemangku kepentingan lainnya yang kepentingannya telah dirusak oleh penerapan praktik manajemen laba. Di bawah skema seperti itu, CSR digunakan sebagai mekanisme entrenchment. Pernyataan tersebut diperkuat dengan pernyataan literatur lain dimana manajer yang tidak efisien kemudian memiliki motif khusus untuk berkomitmen pada perilaku yang bertanggung jawab secara sosial yang mendapatkan dukungan dari para pemangku kepentingan (Muriithi, 2021).

Sebagai bagian dari strategi entrenchment, manajer melakukan earnings management untuk memastikan stabilitas arus kas sehingga mereka dapat memenuhi kepentingan jangka pendek pemegang saham. Selain itu juga untuk menghilangkan kemungkinan masalah jangka menengah yang menempatkan pekerjaan manajer berada dalam risiko manajer akan meningkatkan CSR performance untuk memuaskan kepentingan kelompok non-pemegang saham (Di Meo, 2017).

Melalui tindakan CSR, manajer berusaha mencapai tujuan yang berbeda untuk mendapatkan beberapa hal seperti liputan yang mampu memberikan keuntungan dari media, legitimasi dari komunitas, regulasi atau peraturan yang menguntungkan; dan mendapatkan pengawasan yang kurang dari investor serta karyawan. Pada dasarnya, seorang manajer percaya bahwa mereka dapat mengurangi kemungkinan diteliti dengan cermat oleh para pemangku kepentingan yang puas terkait tindakan pengelolaan pendapatan yang dilakukan serta mampu menggambarkan citra kepedulian, kesadaran sosial dan lingkungan di dalamnya. Manajer menjadi lebih berkubu (entrench) ketika mereka merasa memiliki kekuatan yang dimana kekuatan ini seringkali mereka dapatkan karena memiliki peran ganda dalam jabatan mereka yaitu sebagai CEO dan ketua serta faktor lainnya yang mempengaruhi kekuatan mereka seperti kepemilikan jangka panjang dan kepemilikan saham (Veprauskaite \& Adams, 2013)

CEO entrenchment akan meningkat seiring waktu atau masa jabatan dari seorang CEO (CEO tenure) dimana pada awal masa jabatan mereka, CEO perlu mengembangkan keterampilan kepemimpinan mereka untuk memenuhi tuntutan pekerjaan baru mereka. Setelah itu, seiring bertambahnya masa jabatan CEO kemungkinan oportunisme manajerial meningkat (Shen, 2003). Kerentanan awal dimana oportunisme manajerial meningkat terjadi ketika masa jabatan CEO kurang dari, atau sama dengan, tiga tahun. Kemudian setelah masa jabatan tiga tahun, CEO mulai mendapatkan kekuasaan dan menjadi semakin mengakar di perusahaan atau bercokol (entrenched).

\section{$\mathrm{H}_{2}$ : tenure CEO memperlemah pengaruh corporate social responsibility terhadap earnings management}

\section{Management Ownership, Corporate Social Responsibility, dan Earning Management}

CEO lebih berpihak pada tingkat menengah kepemilikan manajerial. Ketika kepemilikan CEO di bawah batas bawah, pasar modal dapat memaksa CEO untuk memuaskan kepentingan pemegang saham. Sebaliknya, ketika tingkat kepemilikan ekuitas manajerial naik melampaui tingkat tertentu (sekitar 18\%), tujuan manajerial mulai tertanam. Pendampingan internal dan disiplin eksternal menjadi lemah. Lemahnya kontrol atau monitoring atas manajemen dapat memperkuat kemampuan manajer untuk bersikap oportunis, yaitu mengejar keuntungan mereka sendiri dan mengorbankan nilai perusahaan, dengan menggunakan kebijakan perusahaan yang kurang optimal.

Kepemilikan yang memiliki persentase lebih besar akan mampu memberikan manajer dengan entrenchment yang lebih dalam dan mampu memperbesar ruang lingkup atas perilaku oportunistik (Kazemian \& Sanusi, 2015). Perusahaan dengan besar kepemilikan saham manajerial pada rentang 
tertentu, akan cenderung melakukan manipulasi laba meskipun perusahaan tersebut melakukan CSR. Dengan kata lain, sisi etika perusahaan akan menurun saat manajer memiliki saham lebih dari 18 persen dan kurang dari 50 persen.

$\mathrm{H}_{3}$ : kepemilikan saham ceo memperlemah pengaruh corporate social responsibility terhadap earnings management

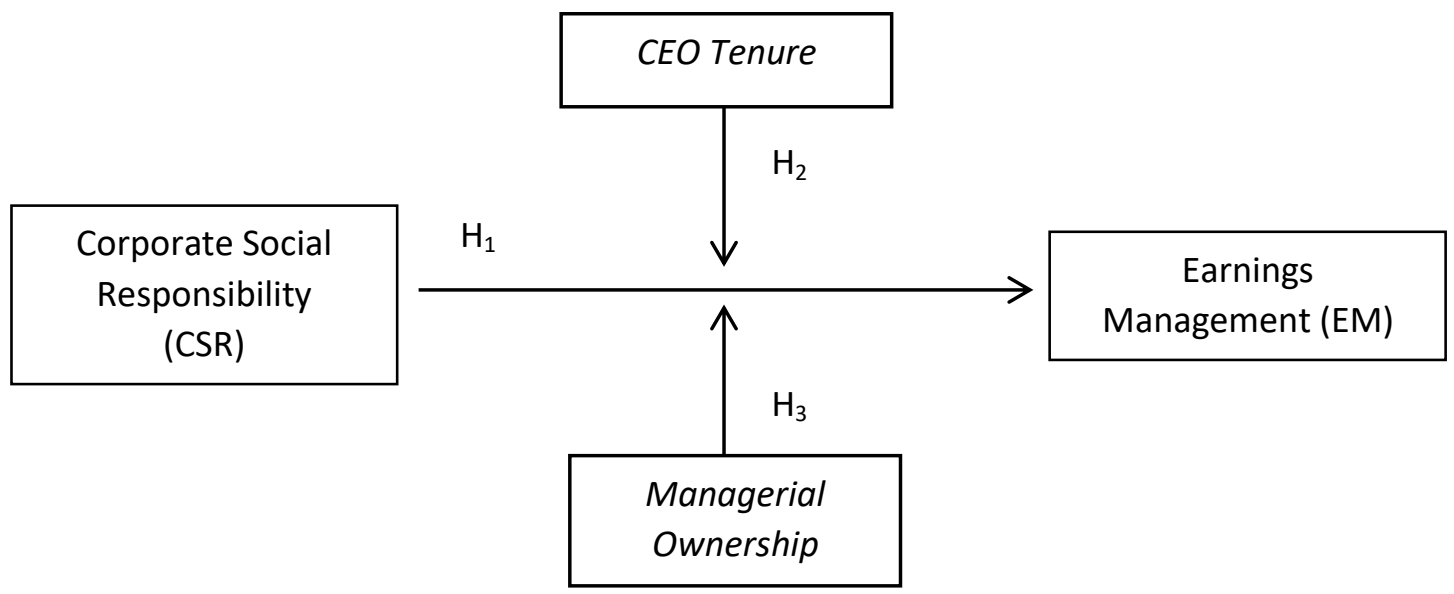

Gambar 1. Kerangka Berfikir

\section{METODE PENELITIAN}

Penelitian ini adalah penelitian kuantitaif deskriptif. Populasi dalam penelitian ini adalah seluruh perusahaan di industri manufaktur yang telah terdaftar di Bursa Efek Indonesia. Sampel dipilih menggunakan metode purposive sampling dengan kriteria, yaitu: (1) perusahaan yang bergerak di bidang manufaktur dan terdaftar di Bursa Efek Indonesia Periode 2016-2018, (2) memiliki laporan keuangan yang sudah diaudit per 31 Desember dari tahun 2016-2018 dan annual report dari tahun 2015-2018, (3) perusahaan yang memiliki informasi terkait CSR CEO tenure, dan managerial ownership. Dengan demikian diperoleh sampel sebanyak 133 perusahaan.

Analisis data menggunakan analisis regresi berganda untuk menguji pengaruh antara corporate social responsibility dan earnings management dengan mempertimbangkan CEO tenure dan Managerial Ownership sebagai variabel moderasi $\left(\mathrm{H}_{1}, \mathrm{H}_{2}\right.$, dan $\left.\mathrm{H}_{3}\right)$. Berikut model yang digunakan dalam penelitian ini.

$$
\begin{aligned}
& \mathrm{H}_{1}: E M=\beta 1 C S R+\beta 2 \text { Size }+\beta 3 R O A+\beta 4 \text { MarketCap }+\beta 5 \text { Leverage }+\beta 6 W C \\
& \mathrm{H}_{2}: \text { a. } E M=\begin{array}{c}
\beta 1 C S R+\beta 2 C E O t+\beta 3 \text { Size }+\beta 4 R O A+\beta 5 \text { MarketCap }+\beta 6 \text { Leverage }+ \\
\beta 7 W C
\end{array}
\end{aligned}
$$

$$
\text { b. } E M=\beta 1 C S R+\beta 2 C E O t+\beta 3 C S R * C E O t+\beta 4 \text { Size }+\beta 5 R O A+\beta 6 \text { MarketCa } \beta 7 \text { Leverage }+
$$
$\beta 8 W C$

$H_{3}:$ a.EM $=\beta 1 C S R+\beta 2 M a n O+\beta 3$ Size $+\beta 4 R O A+\beta 5$ MarketCap $+\beta 6$ Leverage $\beta 7 W C$ 


$$
\begin{aligned}
\text { b. } E M= & \beta 1 \text { CSR }+\beta 2 \text { ManO }+\beta 3 \text { ManO } * \text { CSR }+\beta 4 \text { Size }+\beta 5 R O A+\beta 6 \text { MarketCap }+ \\
& \beta 7 \text { Leverage }+\beta 8 W C
\end{aligned}
$$

$$
\text { CSRGap }=\beta 1 \text { CEOt }+\beta 2 \text { ManO }+\beta 3 \text { Size }+\beta 4 R O A+\beta 5 \text { MarketCap }+\beta 6 \text { Leverage }+\beta 7 W C
$$

Keterangan untuk model tersebut adalah dimana EM adalah Earnings management menggunakan model Dechow dkk. (1995). CSR adalah Corporate social responsibilit yang diukur menggunakan instrumen pengukuran Hawn \& loannou (2016) yang membedakan aktifitas CSR untuk pihak internal dan eksternal perusahaan. CEOt adalah masa jabatan CEO yang diberi skor 1 jika masa jabatan CEO lebih besar dari tiga tahun, dan 0 jika kurang dari tiga tahun. ManO adalah Kepemilikan saham manajer yang diberi nilai 1 jika proporsi saham CEO atas total saham perusahaan jatuh ke dalam kisaran 18,08\% dan 50,06\%, dan sebaliknya (Di Meo dkk., 2017). Size adalah ukuran perusahaan yang diukur dengan logaritma natural dari total aset. ROA adalah Return on Asset yang diukur sebagai rasio income dengan total aset. MarketCap adalah market capital yang diukur dengan rasio pasar terhadap buku. Leverage adalah hutang perusahaan yang diukur sebagai total hutang dibagi dengan total aset. WC adalah working capital yang diukur sebagai perbedaan antara aset lancar dan kewajiban lancar. CSRGap adalah kesenjangan CSR yang berasal dari nilai absolut dari perbedaan aktivitas CSR internal dan eksternal (Hawn \& loannou, 2016).

\section{HASIL DAN PEMBAHASAN}

Pada tabel deskriptif terlihat bahwa nilai tertinggi EM adalah 0,499 dan nilai terendah EM adalah -0,214. Nilai rata-rata CSR yang dilakukan seluruh badan usaha yang menjadi sampel penelitian adalah sebesar 0,5066 . CEO Tenure menunjukkan persentase $45,1 \%$ untuk masa jabatan kurang dari tiga tahun, dan $54,9 \%$ masa jabatan kurang dari tiga tahun. Kepemilikan saham manajerial dari 323 perusahaan ada pada rentang $18,08 \%-50,06 \%$, sedangkan pada 43 perusahaan lainnya, kepemilikan saham manajerial kurang dari $18,08 \%$ atau lebih dari 50,06\%.

Tabel 2. Statistik Deskriptif

\begin{tabular}{lcrrrr}
\hline Variabel & N & \multicolumn{1}{c}{ Minimum } & Maximum & \multicolumn{1}{c}{ Mean } & Std.Deviation \\
\hline EM & 366 & $-0,989$ & 0,499 & $-0,022$ & 0,111 \\
CSR & 366 & 0,042 & 0,994 & 0,507 & 0,188 \\
CSR Gap & 366 & $-0,542$ & 0,000 & $-0,245$ & 0,100 \\
SIZE & 366 & 24,417 & 33,474 & 28,538 & 1,592 \\
ROA & 366 & $-0,599$ & 2,324 & 0,043 & 0,162 \\
Leverage & 366 & 0,000 & 5,073 & 0,579 & 0,578 \\
MarketCap & 366 & $7,800, \mathrm{E}+09$ & $5,502, \mathrm{E}+14$ & $1,865, \mathrm{E}+13$ & $6,438, \mathrm{E}+13$ \\
WC & 366 & $-1,399, \mathrm{E}+13$ & $3,546, \mathrm{E}+13$ & $1,503, \mathrm{E}+12$ & $4,979, \mathrm{E}+12$ \\
\hline
\end{tabular}

Berdasarkan Tabel 3, pengujian yang dilakukan menunjukkan hasil bahwa variabel CSR memberikan pengaruh negatif yang signifikan terhadap EM. Pengaruh negatif mengartikan bahwa perusahaan yang melakukan tindakan CSR dalam perusahaannya cenderung tidak melakukan manajemen laba atau lebih sedikit melakukan tindakan manajemen laba (Hong \& Andersen, 2011). Hal tersebut disebabkan karena CSR terkait dengan aspek etika dan moral tentang pengambilan keputusan dan perilaku perusahaan (McWilliams, 2011). Hasil ini selaras dengan penelitian terdahulu yang mengungkapkan bahwa CSR dengan EM memiliki hubungan negatif (Almahrog dkk., 2018; GarcíaSánchez dkk., 2020; Gras-Gil dkk., 2016; Scholtens \& Kang, 2013). 
Tabel 3. Hasil Regresi Hipotesis 1 dan 2

\begin{tabular}{lccrrrr}
\hline & \multicolumn{2}{c}{ Model 1 } & \multicolumn{2}{c}{ Model 2 } & \multicolumn{2}{c}{ Model 3 } \\
\cline { 2 - 7 } & \multicolumn{1}{c}{ t } & Sig & \multicolumn{1}{c}{ S } & \multicolumn{1}{c}{ Sig } & \multicolumn{1}{c}{ S } & \multicolumn{1}{l}{ ig } \\
\hline Constant & $-2,461$ & 0,007 & $-2,414$ & 0,008 & $-2,406$ & 0,008 \\
CSR & $-1,735$ & 0,042 & $-1,629$ & 0,052 & $-1,511$ & 0,066 \\
CEO & & & 0,393 & 0,347 & $-0,329$ & 0,371 \\
tenure & & & & & & \\
CSR CEO & & & & & 0,496 & 0,310 \\
tenure & & & & & & \\
SIZE & 2,233 & 0,013 & 2,145 & 0,017 & 2,189 & 0,015 \\
ROA & 8,621 & 0,000 & 8,539 & 0 & 8,541 & 0,000 \\
Leverage & $-1,540$ & 0,062 & $-1,553$ & 0,061 & $-1,538$ & 0,063 \\
MarketCap & -3.442 & 0,001 & $-3,403$ & 0,001 & $-3,396$ & 0,001 \\
WC & 0,380 & 0,352 & 0,379 & 0,353 & 0,328 & 0,372 \\
\hline
\end{tabular}

Kemudian pada pengujian selanjutnya, didapatkan hasil bahwa variabel CEO tenure yang merupakan proksi dari managerial entrenchment tidak memberikan pengaruh yang signifikan terhadap hubungan variabel CSR dengan EM. Hasil dari regresi menunjukkan bahwa variabel CSR mengalami penurunan signifikansi ketika variabel CEO tenure dimasukkan kedalam model regresi baik sebagai variabel independen maupun variabel moderasi. Artinya semakin lama masa kerja CEO maka semakin mendorong CEO untuk semakin loyal atau berkomitmen terhadap perusahaan sehingga masa kerja CEO tidak akan memperlemah hubungan negatif antara CSR dengan EM. Alasan yang mendasari temuan ini adalah manipulasi pendapatan menurut banyak orang tidak pantas secara etika, terjadi lebih jarang di perusahaan-perusahaan dengan komitmen kuat terhadap tanggung jawab sosial (Botero dkk., 2004).

Tabel 4. Hasil Regresi Hipotesis 3

\begin{tabular}{lrrrr}
\hline & \multicolumn{2}{c}{ Model 4} & \multicolumn{2}{c}{ Model 5 } \\
\cline { 2 - 5 } & \multicolumn{1}{c}{$\mathrm{t}$} & Sig & \multicolumn{1}{c}{$\mathrm{t}$} & \multicolumn{1}{l}{ Sig } \\
\hline Constant & $-2,474$ & 0,007 & $-2,471$ & 0,007 \\
CSR & $-1,732$ & 0,042 & $-1,653$ & 0,049 \\
Managerial Ownership & 0,284 & 0,388 & 0,099 & 0,461 \\
CSR*ManO & & & $-0,007$ & 0,497 \\
SIZE & 2,250 & 0,012 & 2,245 & 0,012 \\
ROA & 8,517 & 0 & 8,493 & 0 \\
Leverage & $-1,501$ & 0,067 & $-1,499$ & 0,067 \\
MarketCap & $-3,41$ & 0,001 & $-3,403$ & 0,001 \\
WC & 0,372 & 0,355 & 0,371 & 0,356 \\
\hline
\end{tabular}

Berdasarkan pengujian yang dilakukan, managerial ownership yang juga merupakan proksi dari managerial entrenchment tidak memberikan pengaruh yang signifikan terhadap hubungan CSR dengan EM. Ketika variabel managerial ownership ditambahkan dalam model baik sebagai variabel independen maupun variabel moderasi tidak memberikan pengaruh yang signifikan terhadap signifikansi CSR 
Steven Khosasi: Corporate Social Responsibility ...

terhadap EM. Di sisi lain, managerial ownership sendiri juga tidak memiliki atau tidak memberikan pengaruh yang signifikan terhadap variabel dependen EM.

Tabel 5. Robustness Test (Uji Ketahanan)

\begin{tabular}{lrl}
\hline & \multicolumn{2}{c}{ Model 6 } \\
\hline Constant & $\mathrm{t}$ & $\mathrm{Sig}$. \\
CEO Tenure & 1,750 & 0,041 \\
ManOwnership & $-0,273$ & 0,026 \\
SIZE & 0,392 \\
ROA & $-4,139$ & 0,000 \\
Leverage & $-3,392$ & 0,001 \\
MarketCap & 1,106 & 0,135 \\
WC & $-1,315$ & 0,095 \\
\hline
\end{tabular}

Peneliti juga melakukan uji ketahanan (robustness test) terhadap variabel CEO tenure dan managerial ownership yang merupakan proksi managerial entrenchment terhadap CSR Gap (Kesenjangan CSR). Hasil pada pengujian menunjukkan bahwa variabel CEO tenure memberikan pengaruh yang signifikan terhadap variabel CSR gap. CSR internal berkaitan terhadap perubahan kebijakan perusahaan, sedangkan CSR eksternal berkaitan dengan komunikasi untuk mendapatkan dukungan publik. Semakin lebar kesenjangannya maka semakin banyak tindakan internal yang dilakukan perusahaan daripada eksternal dan menyebabkan kurangnya transparansi dan akuntabilitas terhadap komunitas investor.

Hal tersebut dimanfaatkan oleh perusahaan dengan tujuan untuk menghindari risiko terhadap pandangan analis investasi atau lembaga pemeringkat lainnya (Hawn \& loannou, 2016). Sedangkan pada hasil pengujian variabel managerial ownership menunjukkan bahwa managerial ownership tidak memberikan pengaruh yang signifikan terhadap CSR Gap. Artinya kepemilikan CEO dalam perusahaan tidak memiliki pengaruh baik terhadap hubungan CSR dan EM maupun dengan kesenjangan CSR (CSR Gap). Pengaruh yang tidak signifikan dan bersifat negatif tersebut dikarenakan hanya sebagian kecil dari perusahaan yang diklasifikasikan sebagai entrenchment menggunakan managerial ownership (11,7\%) dalam mengontrol perusahaan dibandingkan dengan CEO Tenure $(54,9 \%)$ yang lebih banyak digunakan sebagai entrenchment dalam mengontrol perusahaan (Di Meo dkk., 2017).

Aktifitas CSR perusahaan merupakan bentuk pengaturan diri untuk membatasi serangkaian tindakan negatif, yang dapat diadopsi oleh perusahaan ketika berinteraksi dengan pemangku kepentingan. Ketika perusahaan terlibat dalam kegiatan CSR, artinya lebih sedikit ruang untuk oportunisme manajerial dan memberi insentif yang lebih besar untuk meningkatkan nilai perusahaan. Hal tersebut terbukti dalam penelitian ini, CSR mampu mengurangi tindakan manipulasi laba walaupun manajemen terjadi entrenchment. Selanjutnya, semakin lama masa kerja CEO - yang merupakan salah satu ukuran entrenchment, dapat mendorong perusahaan untuk meningkatkan tindakan CSR internal lebih banyak daripada eksternal agar dapat mengurangi transparansi dan akuntabilitas sehingga dapat meminimalkan risiko pada pandangan analis atau lembaga pemeringkat lainnya.

\section{KESIMPULAN}

Hasil dari pengujian hipotesis satu diperoleh bahwa corporate social responsibility berpengaruh negatif terhadap nilai earnings management secara signifikan. Hasil ini menunjukkan bahwa manajemen laba (EM) yang merupakan tindakan tidak beretika cenderung tidak akan dilakukan pada perusahaan yang 
berfokus pada tanggung jawab sosial perusahaan (CSR) yang merupakan tindakan yang beretika. Maka dapat disimplakan, semakin perusahaan berfokus pada tindakan CSR maka praktik manajemen laba akan semakin rendah. Hasil pengujian hipotesis kedua dan ketiga diperoleh bahwa CEO tenure dan managerial ownership yang merupakan proksi dari managerial entrenchment tidak mempengaruhi hubungan CSR dengan EM secara signfikan baik itu sebagai variabel independen maupun variabel moderasi. Hasil ini menunjukkan bahwa CEO tenure dan managerial ownership tidak dapat digunakan sebagai managerial entrenchment dalam mengontrol perusahaan apabila perusahaan berfokus dan berkomitmen penuh dalam tindakan yang beretika yaitu CSR. Oleh karena itu, tindakan managerial entrenchment yang menggunakan CEO tenure dan managerial ownership tidak akan bisa menggunakan tindakan CSR sebagai topeng atau perlindungan diri pihak manajemen dalam melakukan praktik EM dalam perusahaan

Selanjutnya, dalam pengujian dan analisis yang dilakukan ditemukan bahwa managerial entrenchment lebih memiliki hubungan dan pengaruh terhadap CSR Gap. Pernyataan tersebut dibuktikan dengan hasil regresi yang menunjukkan bahwa CEO tenure memiliki atau memberikan pengaruh yang signifikan terhadap variabel CSR Gap dalam pengujian ketahanan (robustness test). Artinya, entrenchment dapat memengaruhi bentuk CSR yang dilakukan oleh perusahaan. Penelitian ini memberikan beberapa implikasi. Pertama, Secara teoritis, penelitian ini memberikan kontribusi kepada konsep legitimasi dengan menunjukkan bahwa keterlibatan dalam kegiatan CSR memiliki efek pada perilaku pelaporan etis perusahaan. Perilaku etis ini dapat membantu perusahaan untuk mencapai dan mempertahankan legitimasi di pasar keuangan. Premis etis dari stakeholder theory menunjukkan bahwa perusahaan yang benar-benar berkomitmen untuk CSR memiliki informasi keuangan dan nonkeuangan yang lebih kredibel. Kedua, managerial entrenchment tidak mampu menurunkan etika perusahaan dalam melaporkan laba, namun dapat menentukan aktifitas CSR lebih banyak ditujukan untuk internal perusahaan dibandingkan pihak eksternal.

\section{DAFTAR PUSTAKA}

Almahrog, Y., Ali Aribi, Z., \& Arun, T. (2018). Earnings Management and Corporate Social Responsibility: UK evidence. Journal of Financial Reporting and Accounting, 16(2), 311-332. https://doi.org/10.1108/JFRA-11-2016-0092

Bebchuk, L., Cohen, A., \& Ferrell, A. (2009). What Matters in Corporate Governance?. The Review of Financial Studies, 22(2), 783-827. https://doi.org/https://doi.org/10.1093/rfs/hhn099

Wang, H. (2011). Managerial Entrenchment, Equity Payout and Capital Structure. Journal of Banking \& Finance, 35, 36-50. https://10.1016/j.jbankfin.2010.07.018

Botero, J. C., Djankov, S., Porta, R. La, Lopez-De-Silanes, F., \& Shleifer, A. (2004). The Regulation of Labor. The Quarterly Journal of Economics, 119(4), 1339-1382. https://doi.org/10.1162/0033553042476215

McWilliams, A., \& Siegel, D. S. (2011). Creating and Capturing Value: Strategic Corporate Social Responsibility, Resource-Based Theory, and Sustainable Competitive Advantage. Journal of Management 37(5), 1480-1495. https://10.1177/0149206310385696

Muriithi, S. G., Walters, B. A., \& McCumber, W. R. (2021). Managerial Entrenchment And Corporate Social Responsibility Engagement: The Role Of Economic Policy Uncertainty. Journal of Management and Governance. https://doi.org/10.1007/s10997-021-09569-7

Choi, B. B., Lee, D., \& Park, Y. (2013). Corporate social responsibility, Corporate Governance And Earnings Quality: Evidence from Korea. Corporate Governance: An International Review, 21(5), 447-467. https://doi.org/10.1111/corg.12033

Dechow, P. M., Sloan, R. G., \& Sweeney, A. P. (1995). Detecting Earnings Management. The Accounting 
Steven Khosasi: Corporate Social Responsibility ...

Review, 70(2), 193-225.

Di Meo, F., García Lara, J. M., \& Surroca, J. A. (2017). Managerial entrenchment and earnings management. Journal of Accounting and Public Policy, 36(5), 399-414. https://doi.org/10.1016/j.jaccpubpol.2017.07.003

Dikolli, S. S., Mayew, W. J., \& Nanda, D. (2014). CEO tenure and the performance-turnover relation. Review of Accounting Studies, 19(1), 281-327. https://doi.org/10.1007/s11142-013-9247-6

Eriandani, R. (2020, January 31). The Economic Impact of Corporate Social Responsibility. 17th International Symposium on Management (INSYIMA 2020).

Eriandani, R., \& Wijaya, L. I. (2021). Corporate Social Responsibility and Firm Risk: Controversial Versus Noncontroversial Industries. Journal of Asian Finance, Economics and Business, 8(3), 953-965. https://doi.org/10.13106/jafeb.2021.vol8.no3.0953

Fatemi, A., Glaum, M., \& Kaiser, S. (2018). ESG performance and firm value: The moderating role of disclosure. Global Finance Journal, 38, 45-64. https://doi.org/10.1016/j.gfj.2017.03.001

García-Sánchez, I. M., Hussain, N., Khan, S. A., \& Martínez-Ferrero, J. (2020). Managerial entrenchment, corporate social responsibility, and earnings management. Corporate Social Responsibility and Environmental Management, 27(4), 1818-1833. https://doi.org/https://doi.org/10.1002/csr.1928

Gras-Gil, E., Palacios Manzano, M., \& Hernández Fernández, J. (2016). Investigating the relationship between corporate social responsibility and earnings management: Evidence from Spain. $B R Q$ Business Research Quarterly, 19(4), 289-299. https://doi.org/10.1016/j.brq.2016.02.002

Hawn, O., \& Ioannou, I. (2016). Mind the gap: The interplay between external and internal actions in the case of corporate social responsibility. Strategic Management Journal Management Journal, 37(13), 2569-2588. https://doi.org/https://doi.org/10.1002/smj.2464

Hong, H. G., \& Liskovich, I. (2015). Crime, Punishment and The Value of Corporate Social Responsibility. SSRN Electronic Journal. https://doi.org/10.2139/ssrn.2492202

Hong, Y., \& Andersen, M. L. (2011). The Relationship Between Corporate Social Responsibility and Earnings Management: An Exploratory Study. Journal of Business Ethics, 104(4), 461-471. https://doi.org/10.1007/s10551-011-0921-y

Kazemian, S., \& Sanusi, Z. M. (2015). Earnings Management and Ownership Structure. Procedia Economics and Finance, 31(15), 618-624. https://doi.org/10.1016/s2212-5671(15)01149-1

Lee, J. W. (2020). CSR impact on the firm market value: Evidence from tour and travel companies listed on chinese stock markets. Journal of Asian Finance, Economics and Business, 7(7), 159-167. https://doi.org/10.13106/jafeb.2020.vol7.no7.159

Liu, M., \& Lu, W. (2019). Corporate social responsibility, firm performance, and firm risk: The role of firm reputation. Asia-Pacific Journal of Accounting \& Economics, 1-21. https://doi.org/10.1080/16081625.2019.1601022

Lyon, T. P., \& Montgomery, A. W. (2015). The Means and End of Greenwash. Organization and Environment, 28(2), 223-249. https://doi.org/10.1177/1086026615575332

Nguyen, P., \& Nguyen, A. (2015). The effect of corporate social responsibility on firm risk. Social Responsibility Journal, 11(2), 324-339. https://doi.org/10.1108/SRJ-08-2013-0093

Perera, L. C. R., \& Chaminda, J. W. D. (2013). Corporate social responsibility and product evaluation: The moderating role of brand familiarity. Corporate Social Responsibility and Environmental Management, 20(4), 245-256. https://doi.org/10.1002/csr.1297

Scholtens, B., \& Kang, F. C. (2013). Corporate Social Responsibility and Earnings Management: Evidence from Asian Economies. Corporate Social Responsibility and Environmental Management, 20(2), 95112. https://doi.org/10.1002/csr.1286

Shen, W. (2003). The Dynamics of The CEO-Board Relationship; an Evolutionary Perspective. 28(3), 466476. 
Suto, M., \& Takehara, H. (2020). Corporate social responsibility intensity, management earnings forecast accuracy, and investor trust: Evidence from Japan. Corporate Social Responsibility and Environmental Management, 27(6), 3047-3059. https://doi.org/10.1002/csr.2022

Veprauskaite, E., \& Adams, M. (2013). Do powerful chief executives influence the financial performance of UK firms? British Accounting Review, 45(3), 229-241. https://doi.org/10.1016/j.bar.2013.06.004 


\section{Universitas Pakuan}

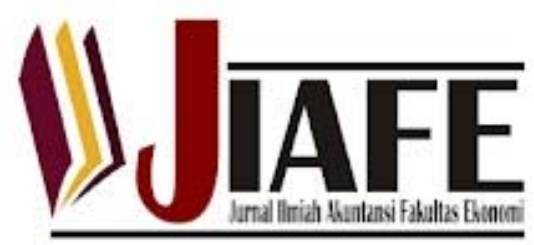

\section{P-ISSN 2502-3020 E-ISSN 2502-4159}

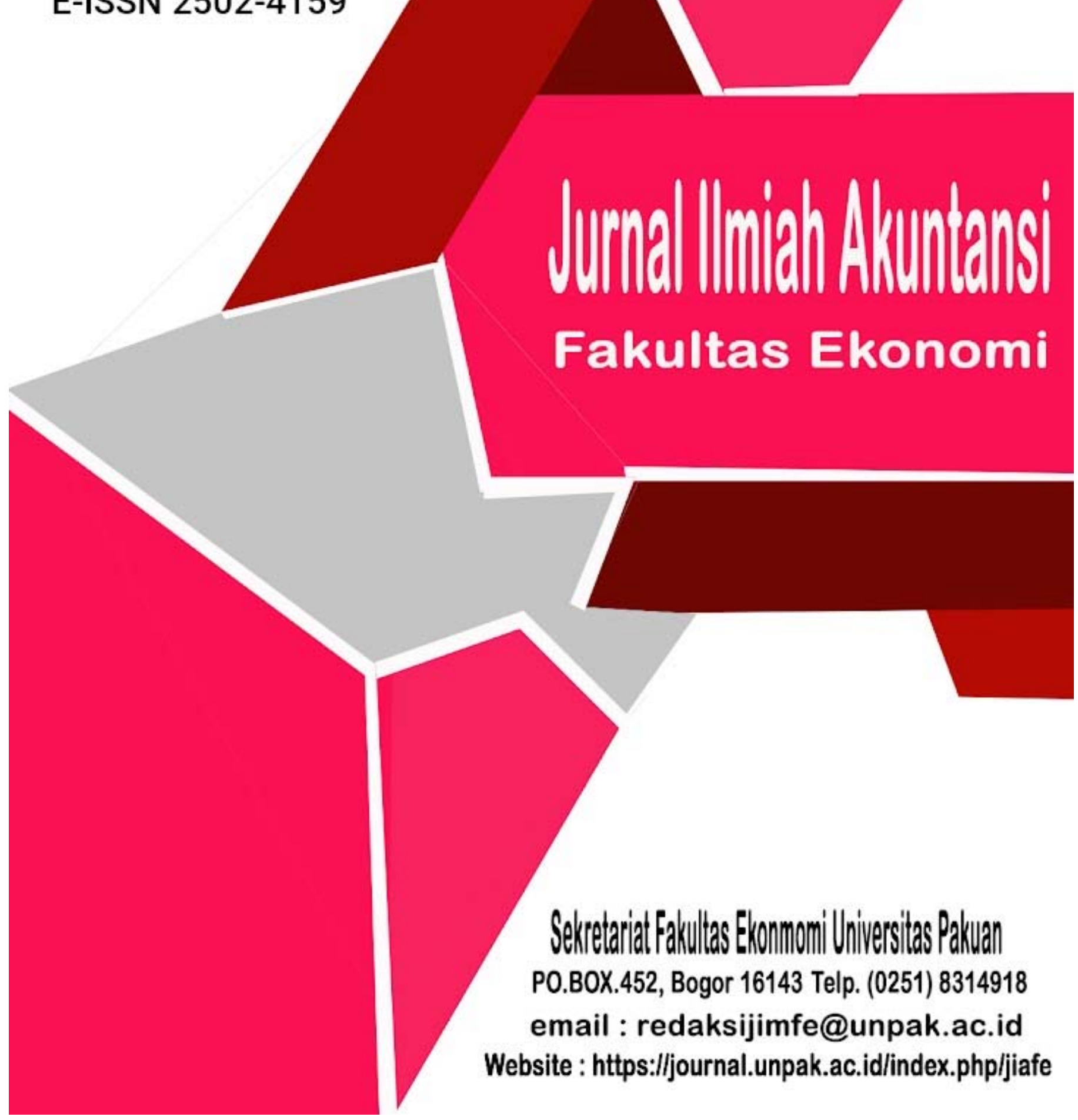




\section{(a) $\begin{aligned} & \text { Universitas } \\ & \text { Pakuan }\end{aligned}$}

\section{JAFEE (UVRNALLLMAHA AKUNTANS FFAULTAS EKONOMI)} E-ISSN 2502-4159 / P-ISSN 2502-3020

Terindeks:

Cinta Ca GARUDA Crossref

Anggota dari:

publons Google Scholar ROAD Dimensions

[L] $]$ AlJ $\overline{E B I}$

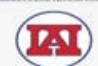

\section{Editorial Team}

\section{Editor in Chief}

1. Hari Gursida, Universitas Pakuan, Indonesia

\section{Editorial Board}

1. Ihyaul Ulum, Universitas Muhammadiyah Malang, Indonesia

2. Suhaimi Bin Rahman, Universiti Putra Malaysia, Malaysia

3. Hamsatulazura Binti Hamzah, Multimedia Universiti, Malaysia

4. Krismiaji Krismiaji, AA YKPN, Indonesia

5. Rahmawaty Hanny Yustrianthe, AA YKPN, Indonesia

6. Tatang Ary Gumanti, Universitas Bhayangakara Jakarta Raya, Indonesia

7. Yudistira Permana, Sekolah Vokasi Universitas Gadjah Mada, Indonesia

8. Rindah Febriana Suryawati, IPB University, Indonesia

9. Nurmala Ahmar, Universitas Pancasila, Indonesia

10. Nurafni Eltivia, Politeknik Negeri Malang, Indonesia

11. Haqi Fadillah, Universitas Pakuan, Indonesia

12. Arief Tri Hardiyanto, Universitas Pakuan, Indonesia

\section{Managing Editor}

1. Mutiara Puspa Widyowati, Universitas Pakuan, Indonesia

\section{IT Support}

1. Reza Ariftiarno, Universitas Pakuan, Indonesia

User 


\section{(a). $\begin{aligned} & \text { Universitas } \\ & \text { Pakuan }\end{aligned}$}

\section{JAFEE (UVRNALLLMAHA AKUNTANS FFRULTAS EKONOMI)}

E-ISSN 2502-4159 / P-ISSN 2502-3020

Terindeks:

\section{@înta CaGARUDA \\ Crossref \\ publons Google Scholar RひAD Dimensions}

Anggota dari:

[LU] A(J)EBI

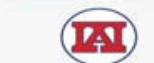

Vol 7, No 1 (2021)

Vol 7, No. 1 (2021)

DOI: https://doi.org/10.34204/jiafe.v7i1 (https://doi.org/10.34204/jiafe.v7i1)

\section{Articles}

APAKAH OPINION SHOPPING, REPUTASI KAP, AUDIT TENURE DAN KONDISI KEUANGAN MEMPENGARUHI OPINI AUDIT GOING CONCERN? (https://journal.unpak.ac.id/index.php/jiafe/article/view/2928)

Ribkha Laura, Husnah Nur Laela Ermaya, Edi Warman

PDF (https://journal.unpak.ac.id/index.php/jiafe/article/view/2928/pdf) | 1-10

(https://journal.unpak.ac.id/index.php/jiafe/article/view)

(a) Abstract views : 575 (C) views : 172

\section{KEBIJAKAN UTANG PERUSAHAAN TAMBANG YANG TERDAFTAR DI BURSA EFEK INDONESIA}

(https://journal.unpak.ac.id/index.php/jiafe/article/view/2933)

Pandu Adi Cakranegara, Etty Susilowati, Dian Sukma Deti

mPF (https://journal.unpak.ac.id/index.php/jiafe/article/view/2933/pdf) | 11-22

(https://journal.unpak.ac.id/index.php/jiafe/article/view)

(a) Abstract views : 310 낭 views : 117

CORPORATE SOCIAL RESPONSIBILITY DAN EARNINGS MANAGEMENT: MANAGERIAL ENTRENCHMENT

SEBAGAI VARIABEL MODERASI (https://journal.unpak.ac.id/index.php/jiafe/article/view/2869)

Steven Khosasi, Rizky Eriandani

PDF (https://journal.unpak.ac.id/index.php/jiafe/article/view/2869/pdf) | 23-34

(https://journal.unpak.ac.id/index.php/jiafe/article/view)

(). Abstract views : 287 (?) views : 92

DETERMINASI INTEGRITAS LAPORAN KEUANGAN PERUSAHAAN GO PUBLIC DI BURSA EFEK INDONESIA

(https://journal.unpak.ac.id/index.php/jiafe/article/view/2615)

Intan Nurul Oktaviani, Husnah Nur Laela Ermaya, Dwi Jaya Kirana

PDF (https://journal.unpak.ac.id/index.php/jiafe/article/view/2615/pdf) | 35-48 
(https://journal.unpak.ac.id/index.php/jiafe/article/view)

Abstract views : 617 (?) views : 171

ALOKASI ANGGARAN, INTELLECTUAL CAPITAL, KINERJA KEUANGAN, DAN INDIKATOR KINERJA UTAMA BADAN LAYANAN UMUM (https://journal.unpak.ac.id/index.php/jiafe/article/view/2915)

Setyo Budi Hartono, Wahab Zaenuri, Fania Mutiara Savitri, Dessy Noor Farida, Yuyun Ristianawati

PDF (https://journal.unpak.ac.id/index.php/jiafe/article/view/2915/pdf) | 49-62

(https://journal.unpak.ac.id/index.php/jiafe/article/view)

Abstract views : 293 Q views : 99

FINANCIAL RATIOS AND FINANCIAL DISTRESS IN RETAIL TRADE SECTOR COMPANIES

(https://journal.unpak.ac.id/index.php/jiafe/article/view/3380)

Hendro Sasongko, Agung Fajar Ilmiyono, Annisa Tiaranti

PDF (https://journal.unpak.ac.id/index.php/jiafe/article/view/3380/pdf) | 63-72

(https://journal.unpak.ac.id/index.php/jiafe/article/view)

Abstract views : 439 @ views : 148

KESEJAHTERAAN MASYARAKAT, FAKTOR POLITIK, DAN MANAJEMEN RISIKO ORGANISASI TERHADAP OPINI AUDIT LAPORAN KEUANGAN PEMERINTAH DAERAH (https://journal.unpak.ac.id/index.php/jiafe/article /view/3033)

Luky Arjun Darmawan, Kuwat Slamet

PDF (https://journal.unpak.ac.id/index.php/jiafe/article/view/3033/pdf) | 73-88

(https://journal.unpak.ac.id/index.php/jiafe/article/view)

Abstract views : 214 (2) views : 109

FINANCIAL DISTRESS AND EARNINGS MANAGEMENT IN INDONESIA: THE ROLE OF INDEPENDENT COMMISSIONERS (https://journal.unpak.ac.id/index.php/jiafe/article/view/3153)

Vania Agatha Rusci, Setyarini Santosa, Vita Elisa Fitriana

PDF (https://journal.unpak.ac.id/index.php/jiafe/article/view/3153/pdf) | 89-104

(https://journal.unpak.ac.id/index.php/jiafe/article/view)

Abstract views : 583 Q views : 165

DETERMINAN BIAYA AUDIT PADA PERUSAHAAN BUMN (https://journal.unpak.ac.id/index.php/jiafe/article /view/2667)

Rizqa Awalia Rahman, Budi Barata Kusuma Utami

PDF (https://journal.unpak.ac.id/index.php/jiafe/article/view/2667/pdf) | 105-114

(https://journal.unpak.ac.id/index.php/jiafe/article/view)

Abstract views : 219 Q views : 99

FAKTOR INTERNAL PENDORONG TERJADINYA PENGHINDARAN PAJAK PADA PERUSAHAAN SEKTOR INFRASTRUKTUR, UTILITAS, DAN TRANSPORTASI (https://journal.unpak.ac.id/index.php/jiafe/article /view/3046)

Rini Handayani, Endah Purnama Sari, Enny Prayogo, Elvina Elvina

PDF (https://journal.unpak.ac.id/index.php/jiafe/article/view/3046/pdf) | 115-124

(https://journal.unpak.ac.id/index.php/jiafe/article/view)

Abstract views : 451 (C) views : 148

Front Matter 
KOVER (https://journal.unpak.ac.id/index.php/jiafe/article/view/3627)

Jurnal JIAFE

PDF (https://journal.unpak.ac.id/index.php/jiafe/article/view/3627/pdf) |

(https://journal.unpak.ac.id/index.php/jiafe/article/view)

Abstract views : 88 (?) views : 28

User

Username

Password

Remember me

Login

\section{ABOUT JOURNAL}

- Focus and Scope (/index.php/jiafe/about/editorialPolicies\#focusAndScope)

- Editorial Team (/index.php/jiafe/about/editorialTeam)

- Peer Reviewers (/index.php/jiafe/about/displayMembership/28)

- Peer Review Process (/index.php/jiafe/about/editorialPolicies\#peerReviewProcess)

- Publication Ethics (/index.php/jiafe/about/editorialPolicies\#custom-0)

- Online Submissions (/index.php/jiafe/about/submissions\#onlineSubmissions)

- Screening for Plagiarism (/index.php/jiafe/about/editorialPolicies\#custom-3)

- Author Fee (/index.php/jiafe/about/editorialPolicies\#custom-4)

\section{GUIDELINES}

Submission

Guidelines

(https://drive.google.com/file/d

/1TcKIWMeiR7bmNWjo5WjVfVnhyOjK5xkK/view?usp=sharing)

- $\quad$ Author Guidelines (Vindex.php/jiafe/pages/view/authorguidelines)

$\begin{array}{llll}\text { Author } & \text { Guidelines (PDF) (https://drive.google.com/file/d }\end{array}$ /10SpmTkttd7tCOg73IbnSzqM9tjDVgsPg/view?usp=sharing)

- Editor Guidelines (https://drive.google.com/file/d/1DSkTGYHLWkAaOuTxchDxPcKwMvOgw9Ji /view?usp=sharing)

- Reviewer Guidelines (https://drive.google.com/file/d/1bzRxOExsBvNZQggt7kjq-9ssrjed4EiO /view?usp=sharing)

(https://drive.google.com/file/d/15FsT7rcVh1WPCyVaxSkmK0jjY2REmekW /view?usp=sharing) Prosedur dan Kebijakan (https://drive.google.com/file/d /1PvnEkPKmp3tnT52V1oPedOjub_z3QuFF/view?usp=sharing) 
Journal Profile

\section{JIAFE (Jurnal Ilmiah Akuntansi Fakultas Ekonomi)}

eISSN : 25024159 I pISSN : 25023020

Universitas Pakuan

\section{Cînta}

S4

Sinta Score

\section{v Paruda}

Indexed by GARUDA

13

H-Index

13

H5-Index

Citations 


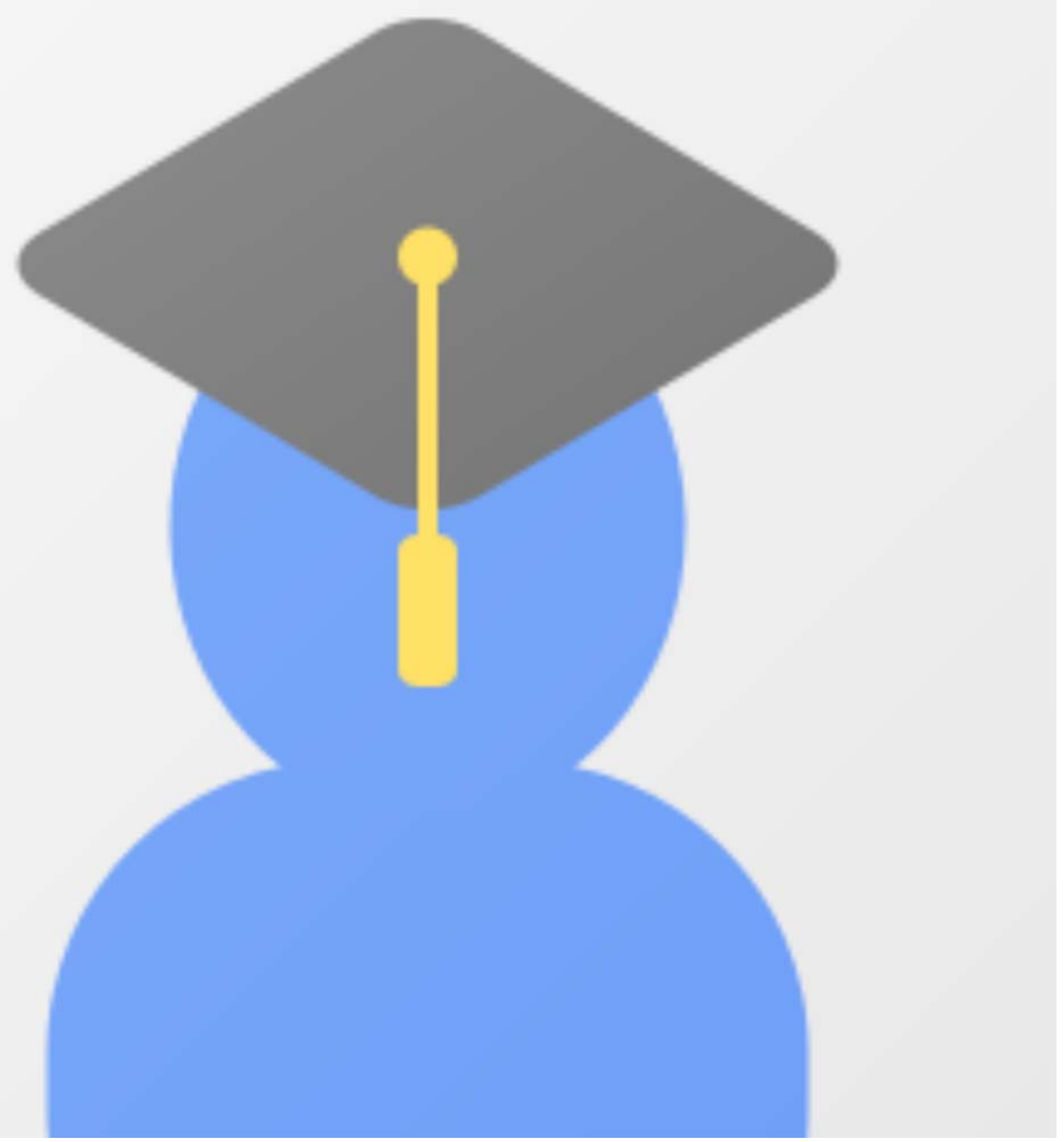

Penerbit:

Fakultas Ekonomi Universitas Pakuan

\section{Website 10 Editor URL}

Address:

Sekretariat Fakultas Ekonomi Universitas Pakuan PO. BOX. 452

KOTA BOGOR

\section{Email:}

redaksijiafe@unpak.ac.id

Phone: 
2022-01-31

2018

2019

Cînta Accreditations

Search..

\section{Q}

\section{$\begin{array}{lllllllll}\mathbf{K} & \ll & 1 & 2 & 3 & 4 & 5 & \gg\end{array}$}

Page 1 of 15 / Total Records : 141

\section{Publications}

Pengaruh Current Ratio, Debt to Asset Ratio, Total Asset Turnover dan Inflasi Terhadap Return on Asset

H Supardi, HSH Suratno, S Suyanto

JIAFE (Jurnal IImiah Akuntansi Fakultas Ekonomi) 2 (2), 16-27

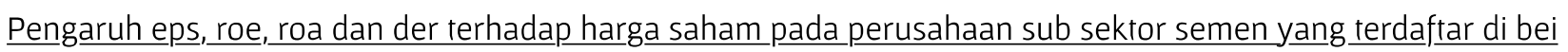

A Alipudin

JIAFE (Jurnal IImiah Akuntansi Fakultas Ekonomi) 2 (1), 1-22

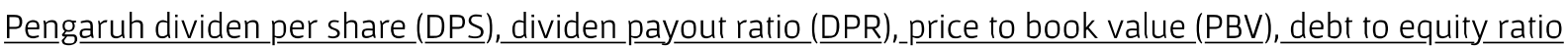

(DER), net profit margin (NPM) dan return on asset (ROA) terhadap ...

E Asmirantho, E Yuliawati

JIAFE (Jurnal Ilmiah Akuntansi Fakultas Ekonomi) 1 (2), 95-117, 2015

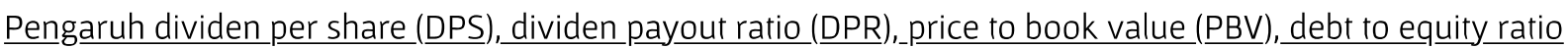

(DER), net profit margin (NPM) dan return on asset $(\underline{R O A})$ terhadap ...

E Asmirantho, E Yuliawati

JIAFE (Jurnal IImiah Akuntansi Fakultas Ekonomi) 1 (2), 95-117

Good Corporate Governance, Conservatism Accounting, Real Earnings Management, And Information

Asymmetry On Share Return

S Sugiyanto, A Candra

Jiafe (Jurnal Ilmiah Akuntansi Fakultas Ekonomi) 4 (1), 9-18

The effect of financial performance on stock price at pharmaceutical sub-sector company listed in Indonesia

stock exchange

E Asmirantho, OK Somantri

JIAFE (Jurnal IImiah Akuntansi Fakultas Ekonomi) 3 (2), 94-107

Pengaruh aset pajak tangguhan dan beban pajak tangguhan terhadap manajemen laba

T Timuriana, RR Muhamad

JIAFE (Jurnal IImiah Akuntansi Fakultas Ekonomi) 1 (2), 12-20

Pengaruh corporate social responsibility terhadap agresivitas pajak dengan insentif_pajak sebagai pemoderasi

(Studi pada perusahaan pertambangan yang terdaftar di BEI) 
Profitability, Leverage, Size of Company Towards Tax Avoidance

K Kimsen, I Kismanah, S Masitoh

JIAFE (Jurnal IImiah Akuntansi Fakultas Ekonomi) 4 (1), 29-36

$\underline{\text { Pengaruh Kualitas Audit, Financial Distress, Debt Default Terhadap Penerimaan Oppini Audit Going Concern }}$

SCI Kesumojati, T Widyastuti, D DARMANSYAH

JIAFE (Jurnal Ilmiah Akuntansi Fakultas Ekonomi) 3 (1), 62-76

Page 1 of 15 | Total Records : 141 